\title{
Better Safe than Sorry - Individual Risk-free Pension Schemes in the European Union
}

\author{
Marga Peeters ${ }^{1}$
}

ABSTRACT

Variations among the diverse pension systems in the member states of the European Union (EU) hamper labor market mobility across national borders and also among firms within the countries of the EU. From a macroeconomic perspective, and in the light of demographic pressure, this paper argues that allowing individual pension accounts instead of collective pension plans would greatly improve labor market flexibility and would thus enhance the functioning of the monetary union. I argue that working citizens would benefit by having their pension funds accumulating in individual pension savings accounts for three reasons. First, citizens would have a clear picture of the accumulation of their own pension savings throughout their working lives. Second, they would pay minimal extra costs, and third, they would not be subject to the whims of governments or other pension fund managers after they retired. This paper investigates the feasibility of individual pension accumulation plans under various parameter settings by calculating the value of the pension saved during a working life and the amount of the pension dis-saved after retirement. The findings show that there are no reasons why the EU and the individual member states should not allow individual pension savings accounts. This approach, as an alternative to forcing workers to participate in one of the various mandatory collective pension schemes that exist in different countries in the EU, would have macroeconomic benefits and would also provide a solid pension program that can enhance mobility.

KEY WORDS: $\quad$ pensions, labor market, monetary union

JEL Classification: G23, H55, H75, H83, J11, J26, J32, J61

${ }^{1}$ NIAS - Royal Netherlands Academy of Arts and Sciences, Netherlands

\section{Introduction}

One in ten European citizens has lived in more than one EU country, usually for work reasons. Job mobility is an indicator of the flexibility of the labor market, and it is vital for the effective functioning of the European Economic and Monetary Union. Nevertheless, individual workers are hampered from moving to more productive jobs or locations by the patchwork of social security systems across the Union (EU, 2012). Workers who frequently change jobs participate in various

!

Corespondence concerning to this article should be addressed to: marga.peeters@gmail.com pension schemes that are administered by different governments and pension funds, and they tend to lose sight of their rights and entitlements. This lack of transparency relating to pension accounts is particularly unfortunate for working EU citizens who change jobs because pension payments can amount to $30 \%$ of a person's gross salary.

Each of the 27 member states of the EU has its own pension system consisting of at least one, but often two or even three components (see also Holzmann \& Palacios, 2001). All countries have a state pension system as the first component, but the pension payments and pension outcomes of the state pension systems differ across countries. For the second component, some 

Quickly matching labor supply and labor demand would not increase unemployment levels. Furthermore, flexible wages could function as a price mechanism to match supply and demand. Excess labor supply in certain countries or regions in the EU could cancel out excess labor demand in other areas of the EU. Flexible labor markets can cushion the effects of asymmetric shocks and can absorb or even prevent future shocks. Moreover, a flexible labor market can keep wage growth moderate and can thereby improve international competitiveness and help to maintain price stability. However, a precondition for the effective functioning of a flexible labor market is that people must be in a position (both financially and socially) to move from one region to another and to thus supply their labor in locations where there is excess demand.

The existing literature shows that labor market mobility in the EU has generally been low (see for instance Cavelaars \& Hessel, 2007; Huber, 2004), even though every EU citizen has the right to live and work in every other country in the EU. As a positive sign, labor mobility within the EU is currently increasing (see Table 1 in Peeters, 2011; European Commission, 2011). In light of demographic developments in the EU, there is expected to be more pressure to increase labor mobility in future decades. According to the population projections of the United Nations, the populations in all EU countries are ageing. This means that there is likely to be a decline in the production of goods and the supply of services, and that there will be less support for fiscal spending on older citizens. A decreasing cohort group of working-age citizens will have to provide health care and other services for an increasing cohort group of elderly citizens. Only a flexible labor market will be able to ensure that enough qualified workers are available to fill existing job vacancies. Unless working-age people who do not currently work full-time become fully available in the labor markets, demographic pressure will encourage more cross-border movement of workers. Temporary contracts that offer additional payments to people so they can be hired rapidly will also contribute positively to the efficient functioning of the labor market because they can make it possible for supply to meet demand on a timely basis. Peeters and Groot (2012) show that among the European countries, the Czech Republic, Poland and Greece will suffer the most from aging populations in terms of pressure on the labor markets and future fiscal expenditures on old-age pensions.

Pensions, particularly non-state pensions, are a major impediment to labor mobility (see Cavelaars \& Hessel, 2007; European Commission, 2010a, b). In most EU countries, domestic pension portability is not easy. Changing jobs often means that the accumulated pension funds remain with the previous pension fund and are not transferred to the fund connected with the new position (see Arza \& Kohli, 2008; Börsch-Supan, 2006; OECD, 2011; Zaidi et al., 2006). Pension portability between EU countries is even more difficult and costly, and it is sometimes impossible. Regulatory systems differ widely, and changing jobs is a time-consuming process that entails high administrative costs. An individual worker who changes jobs is faced with a fragmented accumulation of pension funds that is located with the current employer(s) as well as with various previous employers (see European Commission, 2010a).

Fragmented pension savings and a lack of transparency about the outcome of future pension benefits make people wary. In their search for job market opportunities, people will tend to look within their own countries rather than going across the border to a neighboring EU country unless the wages in the other country are significantly higher (as they are, for example, in countries in the west of the EU compared to countries in the east). A worker who is mobile and who changes jobs within the EU is not only faced with huge differences in the public pension schemes, but also with a wide variety of private schemes across EUcountries. Private schemes are even more varied because some countries have both mandatory and nonmandatory schemes, and in all of these schemes, there are differences in the size of contributions and in the associated benefit outcomes. The accumulated pension entitlements when a person retires are thus a patchwork of different schemes (see Adema \& Ladaique, 2009). Even in cases where an overview of the pension benefits is available, it is not easy to understand.

From a macroeconomic viewpoint, labor mobility should be stimulated instead of being hampered, and mobile workers should be rewarded rather than being punished. Because the average working lifetime is long (often more than 40 years), people usually only start to think about the effective result of their pension funds at a late stage. At that point in life, it is often more dif- 



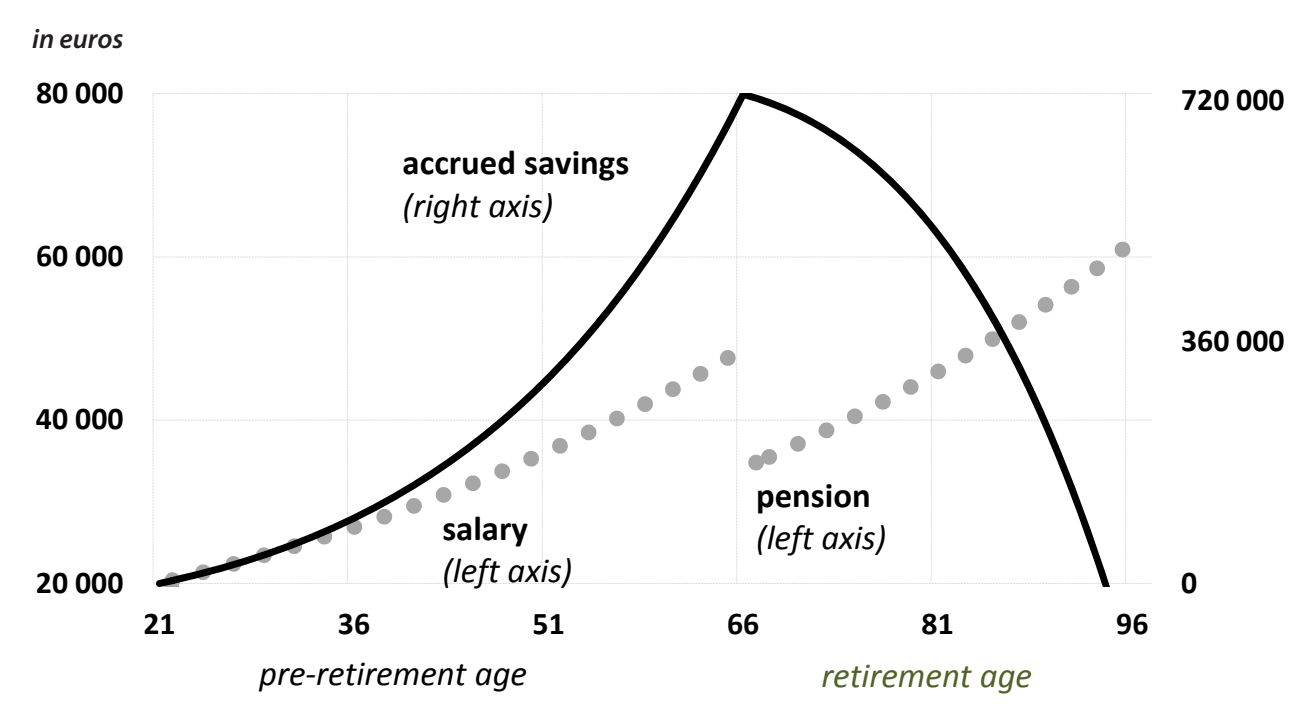

Figure 1. Mr. X's salaries, pension benefits and accumulation of pension funds.

At the age of 67, Mr. X's account is unblocked, and he starts withdrawing money at an annual rate of $70 \%$ of his last earned salary. That amounts to $€ 35,000$ $\left(=€ 49,000^{\star} 0.7\right)$. This is his pension benefit (see the line in Figure 1). In the subsequent years, he withdraws the same amount as the previous year, but with an increase of $2 \%$ to compensate for consumer price inflation. He can do this up until he reaches the age of 94, when his savings reach zero. As the graph illustrates, the decumulation of his savings occurs in a non-linear way because the remaining money in the savings account continues to earn a $4 \%$ interest rate. Because of the fixed long-term savings plan, this interest rate has remained the same over the entire working and retirement period.

This last feature is important. It indicates that the saved contributions are long-term savings and therefore accrue at a relatively high interest rate. Mr. X saves the first pension contribution earned at the age of 22 for 45 years. He also saves the pension contribution earned at age 23 for 45 years because at the age of 67 , he only consumes a small sum of money, and this suffices relative to all the interest accrued on his first salary (earned at the age of 22).

Mr. X does not necessarily have to work his whole life in the same country or with the same employer.
The only relevant parameters in this example are his starting wage (€20,000), the length of his working life (45 years), his annual salary increase (2\%), the pension contributions ( $21 \%$ of his salary, of which $7 \%$ is contributed by the employee and $14 \%$ by the employer), the interest rate on savings (4\%) and the replacement rate at retirement ( $70 \%$ of the last earned salary). The outcome is that Mr. X has secure pension benefits for more than 25 years. With consumer price inflation equaling the nominal increase in the salaries as well as the pension benefits, real income remains at the same level during Mr. X's whole life. The extent to which various combinations of these parameters could lead to higher outcomes in the entire life-cycle income is examined in the next section.

The pension scheme described in the above example is individual because Mr. X possesses all his accumulated funds in a bank account that is only in his name. The scheme is relatively risk-free because $\mathrm{Mr}$. $\mathrm{X}$ receives a fixed interest rate, independent of financial market conditions or other uncertainty factors. Furthermore, this scheme is mandatory because $\mathrm{Mr}$. $\mathrm{X}$ is required to save for his pension and cannot use the accumulated funds for consumption purposes before his retirement. Finally, to use the terminology of pension literature and pension policy discussions, the 
employer and employee have negotiated the pension contributions and not the future pension benefits, so the scheme is a defined contribution (DC) plan and not a defined benefit (DB) plan. In these respects, this scheme is thus rather basic.

It is clear that this example contains many simplifying assumptions. In practice, for example, the level of inflation and the level of interest rates will not remain stable for such a long period. Employees working across borders may even face currency depreciations. However, all of these issues apply in the same way in the current real world without individual pension schemes. The main point here is that the individual savings account in a bank is a much better alternative financially than the current patchwork systems for employees who cross borders to find work.

\section{Straightforward specifications and scenario analyses}

This section specifies, in general terms, Mr. X's lifetime income. The resulting inequalities are used to show pension outcomes under different parameter settings.

\section{Individual pension savings specification}

The pension contributions saved in year $t$, denoted as $S_{t}$, are based on the initial gross wage, $W_{0}$, that grows with $\delta$ and that depends on the rate of pension contributions $\gamma$. It follows that

$S_{t}=\gamma * W_{0}(1+\delta)^{t}$

With $\rho$ the nominal savings interest rate, the accumulated pension savings at the end of the working life of $T$ years are:

PensionSavings $_{T}=\sum_{t=1}^{T} S_{t}(1+\rho)^{T-t}$

Assuming the pension period to be $K$ years, the stream of the pension benefits $P_{t}$ at the age of retirement at period $T$ reads as follows:

PensionNeeds $_{T}=\sum_{t=1}^{K} \frac{P_{t}}{(1+r)^{t}}$

with $r$ the nominal discount rate. In the example of Mr. $\mathrm{X}$, as discussed in the previous section, this discount rate equals the nominal savings interest rate, so $r=\rho$. I generalize in this specification and allow for the pos- sibility that Mr. X could dispose of his savings after his retirement. Therefore, the savings after retirement are no longer long-term savings, so they may mature at a lower interest rate, hence, $r \leq \rho$.

The pension replacement rate, $\mu$, defines the first pension benefit in relation to the last earned wage, $W_{T}$. Adjusted for consumer price inflation,

$P_{1}=\mu * W_{T} *(1+\pi)$

and in the subsequent years, this first pension benefit grows again at the inflation rate $\pi$, so

$P_{t}=P_{1} *(1+\pi)^{t-1}$ for $t=2,3 . . K$.

It should hold that individuals save as much money during their working lives as they need for their retirement. I will consider this a requirement and take the retirement age as the measurement point in time (i.e., year $T$ ). The total lifetime income $\Omega$ in year $T$ (i.e., the stream of pension savings at retirement age $T$ minus the stream of pension needs during the $K$ retirement years) should thus be positive, that is

$\Omega:=$ PensionSavings $_{T}-$ PensionNeed $_{T} \geq 0$

Substituting (2) and (3) in (5) and subsequently substituting (1) and (4a)-(4b) for $S$ and $P$, respectively, it then holds that

$\sum_{t=1}^{T} \gamma * W_{0}(1+\delta)^{t}(1+\rho)^{T-t}-\sum_{t=1}^{K} \frac{\mu * W_{T}(1+\pi)^{t}}{(1+r)^{t}} \geq 0$

$\Leftrightarrow$

$\gamma * W_{0} *(1+\rho)^{T} * \sum_{t=1}^{T}\left(\frac{1+\delta}{1+\rho}\right)^{t}-\mu * W_{T} * \sum_{t=1}^{K}\left(\frac{1+\pi}{1+r}\right)^{t} \geq 0$

$\Leftrightarrow$

$\gamma * W_{0} *\left\{(1+\rho)^{T} * \frac{v^{T+1}-v}{v-1}\right\} \geq \mu * W_{T} *\left\{\frac{w^{K+1}-w}{w-1}\right\}$

with $v:=\frac{1+\delta}{1+\rho}$ and $w:=\frac{1+\pi}{1+r}$.

This last inequality states that the initial pension savings $\left(\gamma * W_{0}\right)$ should precisely match or exceed the pension benefit paid out in the retirement year $\left(\mu * W_{T}\right)$, where this pension saving is accrued to the retirement 
moment by the first term in curly brackets, and this pension benefit is discounted with the second term in curly brackets. Logically, the higher the wage growth $\delta$ during the working life, the higher the accrual of pension funds (the term to the left of the inequality sign). In the same vein, the higher the pension benefit growth $\pi$, the higher the pension needs (the term to the right of the equality sign). However, while the nominal savings rate $(\rho)$ pushes savings upward (the term to the left of the equality sign), higher nominal savings rates after retirement $(r)$ depress the pension needs because the remaining savings accrue more quickly. As an extreme case, which is illustrative, assuming $\delta=\rho=\pi=r=0$, it follows that

$\gamma * W_{0} * T \geq \mu * W_{T} * K$

This implies that the initial pension saving multiplied by the number of working years should precisely match or exceed the initial pension benefit multiplied by the number of retirement years. It is the example of a nongrowing economy without inflation, wage growth or interest payments.

Upon further reflection, it is clear that this case is not so extreme because the same inequality holds if the (wage or price) inflation on income equals the nominal interest rate during an individual's working and retirement life (i.e., $\delta=\rho$ and $\pi=r$ ). This is the case where the return on savings vanishes due to relatively high wage or pension-benefit inflation.

Because it holds that the pension contribution at the moment of retirement is simply the first earned pension contribution accrued with the wage growth (i.e., $\left.W_{T}=W_{0} *(1+\delta)^{T}\right)$, substitution in equation (6) after division of both sides by $W_{0} *(1+\delta)^{T}$ gives

$$
\begin{aligned}
& \gamma * v^{-T} * \frac{v^{T+1}-v}{v-1} \geq \mu * \frac{w^{K+1}-w}{w-1} \\
& \Leftrightarrow \\
& \frac{\gamma}{\mu} \geq \frac{w^{K+1}-w}{w-1} / \frac{v^{T}-1}{v^{T}-v^{T-1}}
\end{aligned}
$$

Interestingly, this shows that the initial wage plays no role in making the pension savings exactly match or exceed the pension needs. This is because a person with a high wage will also receive a proportionately high pension benefit, and a person with a relatively low wage will receive a relatively low pension benefit. However, the parameters that indicate the amount of pension contribution $(\gamma)$ and the pension replacement rate $(\mu)$ as a proportion of the initial wage play a crucial role. Apart from these two parameters, there are six other key parameters.

To summarize, inequality (7) contains the following parameters:

1. The pension contribution rate $\gamma$.

2. The wage growth rate $\delta$.

3. The length of the working life $T$.

4. The nominal rate of return on savings $\rho$.

5. The pension replacement rate $\mu$.

6. The growth rate of pension benefits $\pi$.

7. The length of the retirement period $K$.

8. The discount rate of pension payments $r$.

In the examples below, I assume that some of these parameters are fixed, and I show outcomes for differing values for the other parameters.

\section{Pension outcomes under different scenario settings}

Figure 2 shows preliminary findings, where (7) was used at equality. I first show the trade-off between the number of working years to retirement years, on the one hand, and ration of the pension contribution to replacement rate, on the other hand. The more years that a person works, the lower the pension contribution rate that this person needs, ceteris paribus. In the same vein, the more years that a person needs to receive pension benefits after retiring, the lower the pension replacement rate must be, ceteris paribus, in order for the equality to hold. To illustrate this in an example with numbers, there is a dotted line at the point on the horizontal axis where $T / K=40 / 20=2$ that represents a situation where the individual worker wants to accumulate pension savings for a retirement period of 20 years during a working life period of 40 years (case A). Following the dotted line upwards, one reaches the dark line that represents the isoquant that gives the border between the area on the left (where the inequality (7) does not hold) and the area on the right where it does hold. Then, following the dotted line to the left, one reaches the vertical axis at point 0.27 . This is the pen- 
sion contribution for replacement rate. Assuming that the replacement rate is 0.7 , this implies that the pension contribution is $19 \%$. This is less than the pension contribution in the example with $\mathrm{Mr}$. X in the previous section. With the employer sharing the contributions, and assuming that the employer contributions are twice as high as the worker contributions, this implies that the worker only has to save slightly more than $6 \%$ of his wage rate. Thus, a worker with a retirement period of 20 years and a replacement rate of 0.7 needs to work at least 40 years if the total pension contributions paid in by the worker and the employer amount to $19 \%$ of the wage rate. If the worker works less than 40 years, the total pension contribution paid in by the worker and the employer should be more than $19 \%$.

If this worker only worked 20 years and then had a retirement period of 20 years, the contributions would need to increase considerably. In this case, $\mathrm{T} / \mathrm{K}=20 / 20=1$. This shows (as marked by the dark line) that the pension contribution should be at least 0.7 times the replacement rate. This is case B in the figure. Assuming again a replacement rate of 0.7 , this implies that the pension contribution would have to rise to almost $50 \%$. This would be slightly more than $16 \%$ for the employee if the employer contributed $33 \%$. Interestingly, if the employee worked 30 years and had a retirement period of 30 years, the situation at the isoquant with the dotted line would still hold. See case C. In this case, the ratio of the pension contribution to the replacement rate would drop to 0.6 , and a pension contribution of $40 \%$ would hold for the replacement rate to remain at 0.7 . Working for 10 years longer is thus proportionally more beneficial because the accumulation of funds significantly increases, and this ensures the payment of pension benefits for a much longer period (see also Table 1).

As can be seen in Table 1 (which presents an overview of the required pension contribution rate in the case of different parameter settings), there are ample cases where this contribution is at or below $45 \%$ (that is $15 \%$ for the employee if the employer pays $30 \%$ ). In the standard scenario, the parameters are set at $T=45$, $K=30, \mu=0.7, \delta=\pi=0.02$ and $r=0.03$. The savings interest rate during the working life varies from $0 \%$ to

\section{pension contribution rate / replacement rate}

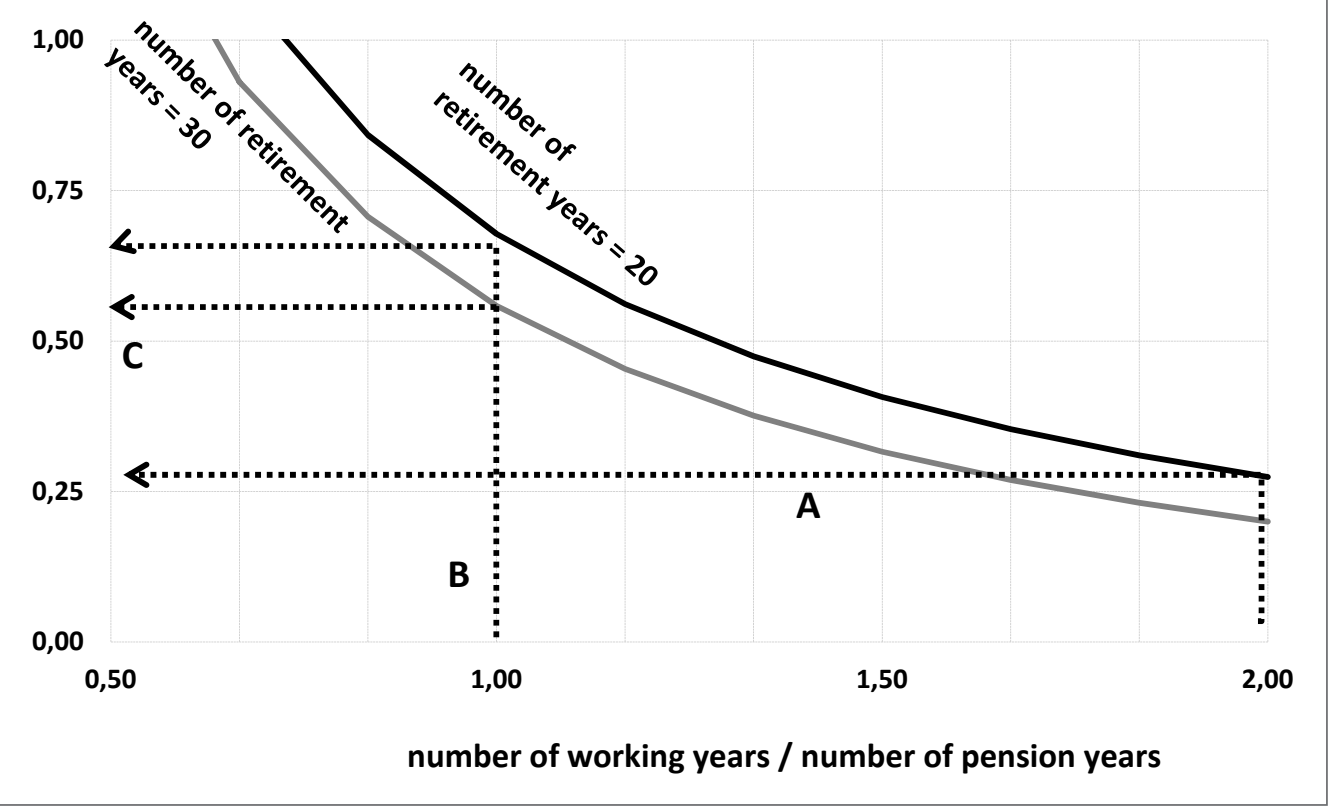

Figure 2. Trade-off of contribution-to-replacement rate and work-to-retirement years 
Table 1. Required pension contribution rate with different parameter settings

\begin{tabular}{|c|c|c|c|c|c|}
\hline savings interest rate & $\rho=0.0$ & $\rho=0.02$ & $\rho=0.04$ & $\rho=0.06$ & $\rho=0.08$ \\
\hline \multicolumn{6}{|c|}{ number of working years } \\
\hline$T=30$ & 0.79 & 0.60 & 0.45 & 0.33 & 0.23 \\
\hline$T=35$ & 0.71 & 0.52 & 0.37 & 0.25 & 0.17 \\
\hline$T=40$ & 0.65 & 0.45 & 0.30 & 0.19 & 0.12 \\
\hline$T=45$ & 0.60 & 0.40 & 0.25 & 0.15 & 0.09 \\
\hline \multicolumn{6}{|c|}{ number of retirement years } \\
\hline$K=20$ & 0.55 & 0.42 & 0.31 & 0.23 & 0.16 \\
\hline$K=25$ & 0.68 & 0.52 & 0.38 & 0.28 & 0.20 \\
\hline$K=30$ & 0.79 & 0.60 & 0.45 & 0.33 & 0.23 \\
\hline$K=35$ & 0.90 & 0.69 & 0.51 & 0.37 & 0.27 \\
\hline \multicolumn{6}{|c|}{ pension replacement rate } \\
\hline$\mu=0.5$ & 0.57 & 0.43 & 0.32 & 0.23 & 0.17 \\
\hline$\mu=0.6$ & 0.68 & 0.52 & 0.39 & 0.28 & 0.20 \\
\hline$\mu=0.7$ & 0.79 & 0.60 & 0.45 & 0.33 & 0.23 \\
\hline$\mu=0.8$ & 0.91 & 0.69 & 0.51 & 0.37 & 0.27 \\
\hline \multicolumn{6}{|l|}{ salary growth } \\
\hline$\delta=0.01$ & 0.70 & 0.52 & 0.38 & 0.28 & 0.19 \\
\hline$\delta=0.02$ & 0.79 & 0.60 & 0.45 & 0.33 & 0.23 \\
\hline$\delta=0.03$ & 0.90 & 0.69 & 0.52 & 0.39 & 0.28 \\
\hline$\delta=0.04$ & 1.01 & 0.79 & 0.60 & 0.45 & 0.33 \\
\hline \multicolumn{6}{|l|}{ pension benefit growth } \\
\hline$\pi=0.01$ & 0.69 & 0.52 & 0.39 & 0.28 & 0.20 \\
\hline$\pi=0.02$ & 0.79 & 0.60 & 0.45 & 0.33 & 0.23 \\
\hline$\pi=0.03$ & 0.92 & 0.70 & 0.52 & 0.38 & 0.27 \\
\hline$\pi=0.04$ & 1.07 & 0.82 & 0.61 & 0.44 & 0.32 \\
\hline \multicolumn{6}{|c|}{ savings rate on pension funds during retirement } \\
\hline$r=0.01$ & 1.07 & 0.82 & 0.61 & 0.44 & 0.32 \\
\hline$r=0.02$ & 0.92 & 0.70 & 0.52 & 0.38 & 0.27 \\
\hline$r=0.03$ & 0.79 & 0.60 & 0.45 & 0.33 & 0.23 \\
\hline$r=0.04$ & 0.69 & 0.53 & 0.39 & 0.28 & 0.20 \\
\hline
\end{tabular}

Note: The standard scenario sets the parameters at $T=45, K=30, \mu=0.7, \delta=\pi=0.02$ and $r=0.03$. Values in bold highlight the cases where the pension contribution is at or lower than $45 \%$. 
$8 \%$ from one column to the next in steps of two percentage points. As can be seen in the top row, a working life of 30 years and a savings interest rate of $4 \%$ requires a pension contribution of $45 \%$. Increasing the working life to 45 years allows this contribution to decrease to $25 \%$. Increasing the working life thus significantly decreases the necessary pension contribution. At this interest rate on savings, if the working life is kept at 45 years but the replacement rate is lowered from 0.7 to 0.5 of the last earned salary, the necessary pension contribution declines from $45 \%$ to $32 \%$, as can be seen in the third panel. Combined scenarios are particularly interesting. For example, with a $4 \%$ savings interest rate, a working life of 45 years and a replacement rate of 0.5 , the required pension contribution falls to only $18 \%$ (not shown in Table 1, but this can be computed by interpolation). Only cases where the savings interest rate is zero are impossible in a practical sense. In such cases, the pension contribution would need to be exorbitantly high because the accumulation of funds would stagnate. Most other situations could be acceptable, even if $\rho$ was only $2 \%$ (i.e., $\rho<r$ ).

In real life, however, an individual worker cannot influence certain factors. Workers are generally unable to influence savings and inflation rates or even the rate of salary growth. However, a worker can choose to work longer and can agree to a lower pension replacement rate. If it is assumed that a worker does not want to pay an individual contribution together with the contribution by his employer to achieve a pension contribution rate of more than $45 \%$, he can calculate the working life and pension replacement rate combination that meets this requirement. One possibility would be for him to work 35 years and to receive $80 \%$ of his last earned salary as pension benefits after retirement. As an alternative, he could accept a compromise where he would receive a pension replacement of $50 \%$ of his last earned salary but he would only need to work for 25 years. This can be seen in Figure 3, where the dark line gives all possible combinations of the replacement rate and the number of working years for $\rho=0.4$. Opting for a lower pension contribution rate of $30 \%$ automatically implies that the worker must work longer to receive the same replacement rate or must agree to a lower replacement rate after the same number of working years.

These calculations show that in terms of feasibility, there are various options available to individual workers to ensure that they will have enough income throughout their lives even if the savings interest rates are moderate. Moreover, in view of the monetary policy objective of

\section{number of working years}

45

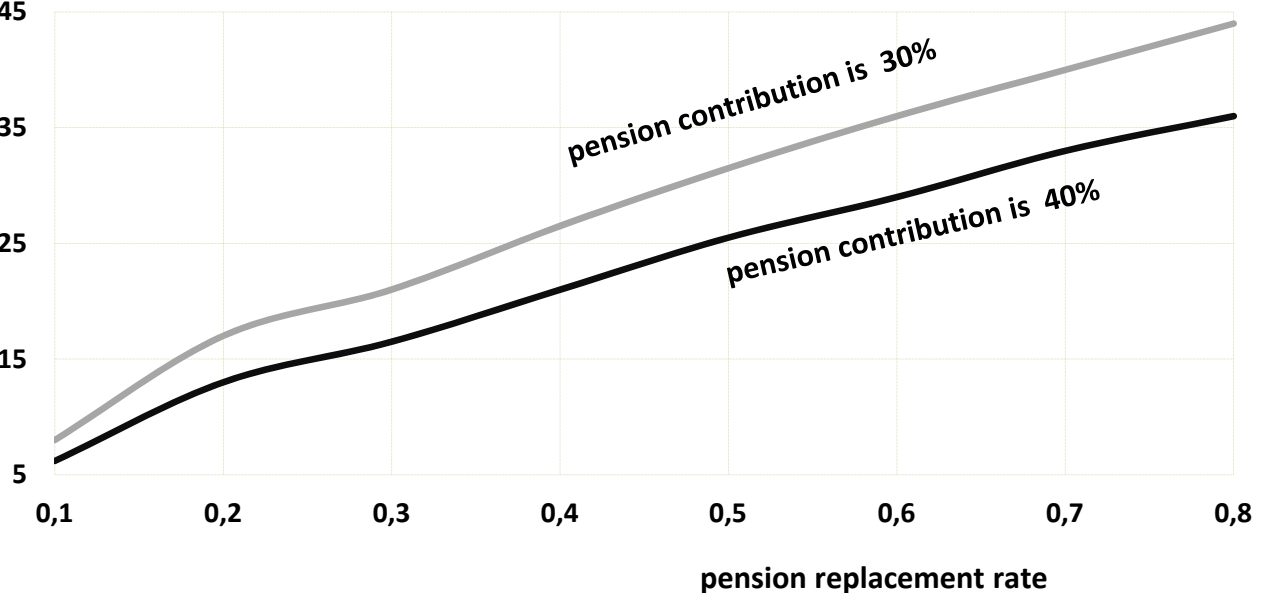

Figure 3. Trade-off between working years and replacement rate at a fixed contribution rate 
price stability in the European Economic and Monetary Union, the inflation and nominal interest rates tend to move in line with each other, so there is little risk of a loss of purchasing power. If inflation increases, (policy) interest rates tend to increase. This keeps the value of the savings in the fund constant. For this reason, the pension benefits retain their value in real terms.

\section{Benefits of individual pension schemes for workers}

The example in section 3 illustrated how Mr. X's pension scheme could work during his life. The generalizations presented in the previous section again underline the possibility of pension savings being sufficient for a long retirement period of even 30 years or more if reasonable pension contributions were made under various parameters of savings rate, inflation and the replacement rate. From the viewpoint of the worker, there are obvious advantages to this individual pension scheme approach in comparison to a collective pension scheme. Moreover, other characteristics associated with savings offer particular advantages.

First, the accumulation and, after retirement, decumulation of funds is transparent for the worker. Placing the funds in an individual bank account that the worker owns prevents anyone else from interfering, deducting money or changing the lump sum apart from the interest payments that are deposited in the blocked account by the bank. This contrasts sharply with the pension schemes that exist in many EU countries that do not give workers any way to see how the nominal values of their pension schemes are increasing during their working lives. It is often only when the retirement age is approaching that workers become aware of their pending pension benefits. Besides making workers more aware, increased transparency can also help them decide whether they need to work more years or fewer years to meet their future income needs (see also Holzmann and Palacios, 2001). In addition, if workers are motivated to leave bequests for survivors, there will be a personal incentive for them to work more. The lump sum of money that the worker sees accumulating in the bank account is an accurate reflection of what has been earned and what will be paid out once the account is unblocked at retirement.

In this regard, the comparison in Sinha (2002) of the Latin American individual pension accounts with the
US system that claimed to achieve a $6 \%$ average rate of return is relevant. Even if stock market investments achieve a higher rate of return, affiliates of a pension fund that have 100 percent investment in stocks may not realize the same rate of return because the ubiquitous management fees can consume much (if not all) of the gain. See also Barr and Diamond (2006) and Hinz et al. (2000) on the magnitude of administration costs associated with individual accounts. It is also appropriate to point out that a $6 \%$ stock market return is overly optimistic. That rate did apply in the period from 1921-1996 is the U.S., but other stock markets worldwide had a far lower return even when dividends were included (see Jorion \& Goetzmann, 1999).

Second, by saving in a simple bank savings account, the worker incurs almost no costs. The total charge for the complete administration of an ordinary bank savings account amounted to 10 to 30 euros per year in 2010. There is no reason for banks to charge higher administration fees in the case of individual savings accounts because these accounts are blocked, so the banks possess each worker's funds over a long period until the worker's retirement age. When the money is used for other purposes, the bank, and not the worker, must assume all the risk. The pension savings should also be fully covered by the national deposit guarantee system.

Because there are no investments in equity or bonds, the bank does not incur any trading costs or additional costs for managing a portfolio of investments. The average operational costs of collective pension funds in 14 countries of the EU range from $0.1 \%$ of the total assets in Denmark and Portugal to more than $1.0 \%$ in the Czech Republic and in Spain (see Graph 7 in Peeters, 2011). The simple average is $0.5 \%$. This is relatively high in comparison with the fixed costs of 10 to 30 euros a year for a bank savings account. These costs significantly depress the returns on the invested funds (comparable with our $\rho$ in the previous section). Moreover, the OECD does not yet have information about the costs of managing pension funds in the remaining 13 countries of the EU. This may indicate that the average costs in the EU are even higher.

Third, with individual pension schemes, workers will no longer be subject to the whims of a government or of other pension fund managers during or after retirement. This independence is a valuable advantage that does not apply to most pension schemes 

these forms of insurance are part of the wider social security system and are not covered by pension funds. Insuring against the loss of earnings through illness is expensive. Moreover, solidarity in relation to these risks is a social issue that is not necessarily the responsibility of the individual employee. While collective pension schemes can relieve borrowing constraints and facilitate intergenerational risk sharing, they usually impose uniform rules on the heterogeneous participants (cited from Bovenberg et al., 2007; see also Barr \& Diamond, 2006). Pension saving over a lifetime, however, is largely in the hands of the worker. Workers should not be punished disproportionally relative to non-workers in view of demographic developments and for the sake of the functioning of the common-market single currency. Moreover, as Holzmann and Palacios (2001) argue, individual accounts are a better way to deal with labor market incentives and changing family patterns, such as divorces, multiple marriages or relationships over the life cycle, widowhood, and the resulting need for independent old-age security for non-working partners. Under an individual account system, the resources accumulated during the period of a marriage can easily be divided after a divorce, combined with each partner's own and prior contributions and interest received, and supplemented by public resources in a transparent manner (e.g., for periods of child rearing).

A third argument against an individual (risk-free) pension scheme is the risk of insufficient coverage and longevity. In the examples presented in the previous sections, one of the assumptions was that workers have perfect foresight and also know how long they will live. If pension savings accrued during a working life are estimated to cover 20 retirement years and the worker lives much longer than that, there will clearly be a financial gap at an age when this is difficult to resolve. This is a real but surmountable problem. Policy makers could impose the life-expectancy age as a guideline for workers and provide the few people who live beyond this set age with an entitlement to a special social security benefit. Alternatively, workers could be legally required to save for a minimum of 30 years of retirement. This period is achievable under reasonable parameter settings, as shown by the calculations in section 4 .

A fourth argument against individual (risk-free) pension schemes is that some people are not capable of doing their own financial planning for such a long period as a lifespan. This objective is often raised but the argument should be regarded as rather weak. Learning to plan is an important skill, and leaving this responsibility to others often results in less attractive outcomes. In the case of savings, as outlined in the previous sections, there are only a few parameters that need to be decided upon (see also Milevsky, 2009; Pozen \& Hamacher, 2011). The pension contribution rate, as well as the workers and employers' share, should be part of the wage-negotiation process. Some kind of pension scheme is already mandatory because there must be savings and the money in the savings account must be inaccessible (blocked), so there are no decisions to make in this regard. The worker does not have to make any investment strategy decisions because the bank will save the worker's funds at the highest interest rate for each payment until the worker's retirement.

There are no other arguments against individual pension schemes in comparison with riskier collective schemes. (I abstain from including in this paper any discussion of term life insurance, which would benefit a worker's survivors.) In case a worker dies, the funds saved in the individual account will be at the disposal of the survivors at the retirement age of the worker. A term life insurance policy is extremely costly (up to $2.5 \%$ of the contributions is charged for management fees), but it is often unnecessary in cases where the survivor is able to work, is entitled to other (social security) funds, or if there are no survivors. Furthermore, general risks such as the risk of inflation affect individual savings accounts and other pension schemes in the same way.

\section{Summary, conclusions and policy recommendations}

Up until now, the economies of the EU have been building collective pension funds. These programs were initiated at a time when there was a great need for solidarity and intergenerational risk-sharing. The movement toward these two national goals, separately or in combination, was in place well before the start of the European Economic and Monetary Union.

However, times have changed. The EU now also has a monetary union. The loss of national discretion on monetary policy, exchange rates and interest rate instruments, and the absence of a common fiscal policy, means that the functioning of the labor market is now of 

regardless of the whims of the government or other fund managers.

Because the difference between the returns on investments in financial markets and the returns and bank savings accounts has diminished over the last decade, and because public finances are currently in trouble, it would not be reasonable to argue on the basis of the potential return on investments that workers should be forced to participate in risky collective investment schemes.

A remaining question that must be answered relates to the steps that EU policy-makers would have to take to implement individual pension schemes throughout the entire EU. This question is easy to answer because this new system could be phased in gradually, and the old patchwork system of pension schemes for employees who work in different EU countries over the course of their working lives could be phased out in the course of time. In this way, the macro-economic cost of moving completely to the new system can also be limited.

Every EU-citizen who takes a job and works in a different country within the EU should be allowed to open a long-term interest-bearing bank savings account that accumulates the monthly pension contributions. These contributions would come from the employee and from the employer, but the precise shares of the pension contributions that would come from the employee and the employer would be determined through the job negotiation process. The savings account should be an EU-wide tax-free, long-term interest-bearing account that is blocked until the moment the EU-citizen reaches the retirement age of, let us say, 67 . This would be what is called a blocked account because no money could be withdrawn until the owner reached the age of 67 , but the value of the account would always be visible to the owner of the account so he or she would be able to keep track of the contribution payments from the employer and interest payments from the bank over the course of time.

Legislation is needed to ensure that banks, or other institutions that function as banks under EU banking supervision, offer these blocked bank accounts under conditions that protect the funds of (former) employees. They must be required to offer these bank accounts at only minor costs because they will have huge sums of long-term savings in their possession and their only obligation will be to pay the long-term interest rate.
This interest rate should be as high as possible for the entire amount in the account from the moment each payment is deposited until the date of the workers' retirement age. The total funds in these pension schemes accounts should be covered by the national deposit guarantee system to ensure that they are risk free. After the age of 67, the EU citizen should receive a monthly payment from this accumulated wealth for a predetermined number of years. Because our calculations show that thirty years is feasible, the payments could continue until the former employee reaches the age of 97 . For individuals who live beyond this age, a safety net should be in place.

At the discretion of the national governments, it will be possible for the EU nations to follow this stepwise implementation of the individual bank-savings-account pension accumulation plan throughout the EU.

\section{References}

Adema, W., \& Ladaique, M. (2009). How expensive is the welfare state? Gross and net indicators in the OECD social expenditures database (SOCX) (Working Papers No. 92). OECD Social, Employment and Migration.

Arza, C., \& Kohli, M. (Eds.). (2008). Pension reform in Europe: Politics, policies and outcome. London: Routledge.

Barr, N. \& Diamond, P. A. (2006). The economics of pensions. Oxford Review of Economic Policy, 22(1), 15-39.

Borgy, V. \& Chojnicki, X. (2009). Labor migration: Macroeconomic and demographic outlook for Europe and neighbourhood regions. International Economics, 3(119), 115-153.

Börsch-Supan, A. (2006). European welfare state regimes and their generosity towards the elderly. (Working Paper No. 479). The Levy Economics Institute of Bard College.

Bovenberg, A. L., Koijen, R. S. J., Nijman, T. E., \& Teulings, C. N. (2007). Saving and investing over the life cycle and the role of collective pension funds. De Economist, 155(4), 347-415.

Cavelaars, P., \& Hessel, J. (2007). Regional labour market mobility in the European Union: Adjustment mechanism or disturbance? (DNB Working Paper No. 137). Netherlands Central Bank, Research Department. 
European Commission. (2012). An agenda for adequate, safe and sustainable pensions, White Paper.

European Commission. (2011). Demography report 2010 - Older, more numerous and diverse Europeans (KE-ET-10-001-EN-C). Luxembourg: Publications Office of the European Union.

European Commission. (2010a). Green Paper - towards adequate, sustainable and safe European pension systems (SEC(2010)830). Brussels: European Comission

European Commission. (2010b). Progress and key challenges in the delivery of adequate and sustainable pensions in Europe (A Joint Report on Pensions) (European Economy Occasional Papers 71, KCAH-10-071-EN-N). Brussels: European Commission Directorate-General for Economic and Financial Affairs Publications

Hinz, R., Rudolph, H., Antolin, P., \& Yermo, J. (Eds.). (2010). Evaluating the financial performance of pension funds. Washington, DC: The World Bank.

Holzmann, R., \& Palacios, R. (2001). Individual accounts as social insurance: A World Bank perspective (Discussion Paper No. 0114), Washington, DC: The World Bank.

Huber, P. (2004). Inter-regional mobility in Europe - A note on the cross-country evidence. Applied Economics Letters, 11(10), 619-624.

Jarret, P. (2011). Pension reforms in Poland and elsewhere: The view from Paris (Network studies \& analyses No. 425), Warsaw, Center for Social and Economic Research (CASE).

Jorion, P., \& Goetzmann, W. N. (1999). Global stock markets in the twentieth century. Journal of Finance, 54(3), 953-980.

Jousten, A., \& Pestieau, P. (2002). Labor mobility, redistribution and pension reform in Europe. In M. Feldstein \& H. Siebert (Eds.), Social Security Pension Reform in Europe (85-108), Chicago, IL: University of Chicago Press.

Milevsky, M. A. (2009). Are you a stock or a bond? Create own pension plan for a secure financial future. New Jersey, NJ: Financial Times Press.

OECD(2011) (2011). Society at a Glance 2011 - OECD Social Indicators. Retrieved from www.oecd.org/ els/social/indicators/SAG

Peeters, M. (2011). "Better safe than sorry" - Individual risk free pension schemes in the European Union
- Macroeconomic benefits, the mobile working citizen's perspective and why nots. (MPRA Working Paper No. 33571). University Library of Munich, Germany.

Peeters, M., \& Groot, L. (2012). Demographic change across the globe - Maintaining social security in ageing economies. World Economics, 13(2), 75-98.

Peeters, M., \& Den Reijer, A. (2012). On wage formation, wage flexibility and wage coordination - A focus on the wage impact of productivity in Germany, Greece, Ireland, Portugal, Spain and the United States (MPRA Working Paper No. 31102). University Library of Munich, Germany.

Pozen, R. C., \& Hamacher, T. (2011). The fund industry: How your money is managed. New Jersey, NJ: Wiley and Sons Inc.

Razin, A., \& Sadka, E. (1999). Migration and pension with international capital mobility. Journal of Public Economics, 74(1), 141-150.

Sinha, T. (2002). Can Latin American's experience teach us something about privatized pensions with personal accounts? Paper presented at Retirement Implications of Demographic and family change symposium in San Francisco.

Van Groezen, B., Kiiver, H., \& Unger, B. (2009). Explaining Europeans' preferences for pension provision. European Journal of Political Economy, 25(2), 237-246.

Zaidi, A., Grech, A. G., \& Fuchs, M. (2006). Pension policy in EU25 and its possible impact on elderly poverty. (CASE Papers case 116), Centre for Analysis of Social Exclusion, LSE. 